[Agr. Biol. Chem., Vol. 34, No. 11, p. 1754 1756, 1970]

\title{
The Effects of Amino Acids on the Growth and Glutamic Acid Decarboxylase Activity of Tobacco Cell Cultures
}

Sir:

The content of $\gamma$-aminobutyric acid $(\gamma$-AB) in the callus tissue of tobacco is very high, and glutamic acid decarboxylase (GAD), which catalyzes the formation of $\gamma-\mathrm{AB}$ from glutamate, is very active. ${ }^{11}$ In the course of the systematic examination for the growth conditions of tobacco cell cultures, we examined the effects of each amino acid and some plant hormones on the growth and the activity of GAD.

The tobacco callus tissue used in the present experiment was obtained from the stem of Nicotiana tabacum L. var. Bright Yellow, and was subcultured for more than two years in the liquid medium. For the examination of the effects of each amino acid, Linsmaier and Skoog inorganic salt medium ${ }^{21}$ supplemented with 2,4-D $(0.2 \mathrm{mg} /$ liter $)$, thiamine-HCl $(0.4 \mathrm{mg} /$ liter), and sucrose (3\%), was used. The cells were grown in $500 \mathrm{ml}$ Erlenmeyer flasks in the medium and inoculum with a total volume of $110 \mathrm{ml}$, dispensed in a $500 \mathrm{ml}$ Erlenmeyer flask containing $1 \mathrm{~mm}$ of one of the amino acids to be tested. The flasks were incubated at $30^{\circ} \mathrm{C}$ in the dark on a reciprocal shaker. After seven-days culture, the cells were harvested by filtration through nylon cloth and weighed for the fresh weight determination. The data presented in Table I are the mean values of five replicates. Glycine, aspartic acid, asparagine, and tyrosine inhibited the growth of tobacco cells by $25 \sim 30 \%$. On

1) A. Koiwai, M. Noguchi and E. Tamaki, Phytochemistry, (in press).

2) E. M. Linsmaier and Skoog, Physiol. Plant., 18, 100 (1965).
Table I. EfFects of Amino Acids on Growth AND ON GLUTAMIC ACID DECARBoxylase ACTIVITY OF TOBACCO CELLS

\begin{tabular}{lccc} 
& \multicolumn{3}{c}{$\begin{array}{c}\text { Glutamic decarboxylase } \\
\text { activity of the cells } \\
\text { Arown in I mM } \\
\text { amino acid }\end{array}$} \\
& $\begin{array}{c}\text { Fresh } \\
\text { weight }\end{array}$ & $\begin{array}{c}\text { per gram } \\
\text { fresh }\end{array}$ & $\begin{array}{c}\text { per } \\
\text { weight }\end{array}$ \\
culture
\end{tabular}

Data are presented as percentage of the control.

a) The fresh weight of the control tissue was $27.4 \mathrm{~g} / 110 \mathrm{ml}$ culture.

b) $\gamma$-Aminobutyric acid formed in $30 \mathrm{~min}$ per gram fresh weight was $11.3 \mu$ moles.

e) $\gamma$-Aminobutyric acid formed in $30 \mathrm{~min}$ per 110 ml culture was $310 \mu$ moles. 
the other hand, glutamine, $\gamma$-AB, phenylalanine, and histidine had no effect on the growth.

Other investigators have examined the effects of amino acid on the cell cultures using ammonia-less nitrogen medium and showed more remarkable inhibition or accerelation of the growth by amino acids. ${ }^{3 \sim 5}$ The medium used in the present experiment contained much ammonia and nitrate nitrogen, and therefore, the cells might not be so remarkably influenced by amino acids.

For the assay of GAD, cells were homogenized in a mortar in cold $0.08 \mathrm{M}$ phosphate buffer, $\mathrm{pH}$ 5.8. The homogenate was centrifuged in a refrigerated centrifuge at $12,000 \times \mathrm{g}$ for $15 \mathrm{~min}$ and the supernatant was used as the enzyme solution. The reaction mixture contained $0.5 \mathrm{ml}$ of the enzyme solution and $0.5 \mathrm{ml}$ of substrate solution ( $1 \%$ solution of sodium glutamate and $0.1 \mathrm{~mm}$ of pyridoxal phosphate) and $1.0 \mathrm{ml}$ of phosphate buffer (0.08 M, pH 5.8). After incubation for $30 \mathrm{~min}$ at $37^{\circ} \mathrm{C}, 0.5 \mathrm{ml}$ of $1 \mathrm{~N} \mathrm{HCl}$ solution was added to the tube and the tube was immersed in boiling water for five min. The content of $\gamma$-AB formed was determined by a Beckman Model 120G Amino Acid Analyzer.

The activity of GAD of the cells grown in the presence of each amino acid $(1 \mathrm{mM})$ is shown in Table I. Glycine, methionine, lysine, and ornithine showed significant repression on GAD. The inducible effect on GAD by amino acids was not certain.

The effect of each amino acid on the catalytic activity of GAD is also observed and the results are summarized in Table II. In this case, the cells were grown in the absence of amino acids, and the assay of the enzyme was performed in the presence of $3 \mathrm{mM}$ of each amino acid. Aspartic acid and tyrosine inhibited the activity remarkably.

3) P. Filner, Biochim. Biophys. Acta, 118, 299 (1966).

4) K. W. Joy, Plant Physiol., 44, 845 (1969).

5) O. L. Gamborg, ibid., 45, 372 (1970).
TABle II. EFFects of Amino ACIDS ON THE Catalytic Activity of Glutamic Acid DECARBOXYLASE (GAD) OF TOBACCO CELLS

\begin{tabular}{lc} 
Amino acid & $\begin{array}{c}\text { GAD activity assayed } \\
\text { with } \begin{array}{c}3 \mathrm{mM} \text { amino } \\
\text { acid }\end{array}\end{array}$ \\
\hline None added & 100 \\
Aspartate & 42 \\
Threonine & 93 \\
Serine & 98 \\
Asparagine & 88 \\
Glutamine & 95 \\
Proline & 92 \\
Glutamate & 72 \\
Glycine & 103 \\
Alanine & 108 \\
Valine & 97 \\
Cysteine & 98 \\
Methionine & 110 \\
Isoleucine & 103 \\
Leucine & 106 \\
Tyrosine & 48 \\
Phenylalanine & 104 \\
Ornithine & 100 \\
Lysine & 108 \\
Histidine & 97 \\
r-Aminobutyrate & 97 \\
Arginine & 89 \\
&
\end{tabular}

Data are presented as percentage of the control.

Other amino acids had no effect on the catalytic activity of GAD.

The effects of some plant hormones on the growth and GAD is shown in Table III. The higher level of 2,4-D content ( $2 \mathrm{mg} /$ liter) showed lower culture yield by fresh weight basis, although no effect was observed on the yield by dry weight basis. Therefore, the cells grown in a higher level of 2,4-D seem to be compact containing a higher percentage of solid material. GAD activity was increased by high level of 2,4-D or NAA.

GAD has been reported to be present largely in non-particulate cytoplasmic fraction 
Table III. EfFects of Plant Hormones on Growth and on Glutamic Acid Decarboxylase (GAD) Activity of Tobacco Cells

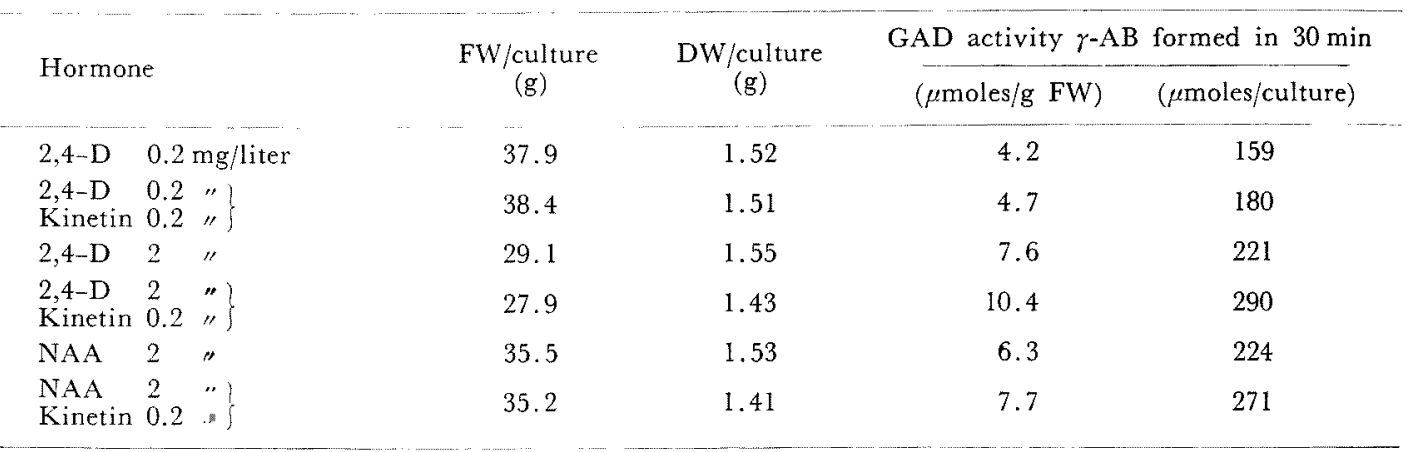

FW: Fresh weight, DW: Dry weight, $\gamma$-AB: $\gamma$-Aminobutyric acid, 2,4-D: 2,4-Dichlorophenoxy acetic acid, NAA: Naphthaleneacetic acid.

in other plant cells, ${ }^{6,7)}$ and we confirmed that also in tobacco cells the enzyme is present in the soluble fraction. Ohno and Okunuki ${ }^{8 !}$ have investigated the inhibition of GAD systematically and shown that popular amino acids had no effect on GAD activity. In the present experiment, aspartic acid and tyrosine

6) B. J. Rogers, Plant Physiol., 30, 186 (1955).

7) R. O. D. Dixon and L. Fowden, Annals Bot., 25, 513 (1961).

8) M. Ohno and K. Okunuki, J. Biochem., 51, 313 (1962). showed remarkable inhibition and cells grown in a high level of 2,4-D or NAA had more increased GAD activity than those grown in a low level of 2,4-D. Further studies are in progress.

\section{Akira KoIwaI \\ Yui TANNO \\ Masao NoguchI}

The Central Research Institute,

Japan Monopoly Corporation,

Nishishinagawa, Shinagawa-ku, Tokyo

Received September 11, 1970 